\title{
IDENTIFIKASI ILUSTRASI-TIPOGRAFI GRAPHIC VERNACULAR SEBAGAI SISTEM TANDA \& IDENTITAS WARUNG TENDA DI KOTA MALANG
}

\author{
Yon Ade Lose Hermanto \\ Program Studi Desain Komunikasi Visual, Jurusan Seni dan Desain Universitas Negeri Malang \\ Email: yonade.fs@um.ac.id
}

\begin{abstract}
Malang City is a city that is developing with the potential in the field of education and a large enough creative industry, has become a destination for urban people who live in other cities to just study or find a livelihood. There are so many immigrants who live temporarily or permanently, because indeed Malang City besides being an educational destination, is also a tourist destination. The existence of urban communities in the city of Malang makes the economic stretch in this city also lifted. Including roadside culinary business. Tent stalls on the side of the road grow mushrooming with a variety of culinary choices. These tent stalls have various kinds of identities that are made with manual techniques to be known and remembered by the community as consumers. These works are called vernacular graphic works, which consist of typography and illustrations. This study is to examine the factors concerned with vernacular graphics which can be used as an identity and sign system. The results of this study are that the vernacular graphics found on tent stalls banners can be an identity as well as a sign system that is easily identified by the community.
\end{abstract}

Keywords: vernacular graphics, tent stalls, identity, sign systems, Malang City

\begin{abstract}
Abstrak : Kota Malang merupakan kota yang tengah berkembang dengan potensi dibidang pendidikan dan industri kreatif yang cukup besar, telah menjadi tujuan bagi masyarakat urban yang bermukim di kota-kota lain untuk sekadar belajar atau mencari mata pencaharian. Banyak sekali pendatang yang bermukim sementara atau menetap, karena memang Kota Malang disamping menjadi destinasi pendidikan, juga menjai destinasi wisata. Keberadaan masyarakat urban di Kota Malang membuat geliat ekonomi di kota ini juga terangkat. Termasuk usaha kuliner pinggir jalan. Warung-warung tenda dipinggir jalan tumbuh menjamur dengan beragam pilihan kuliner. Warung-warung tenda ini memiliki berbagai macam identitas ang dibuat dengan teknik mannual untuk dikenal dan diingat oleh masyarakat sebagai konsumennya. Karya-karya ini disebut dengan karya graphic vernacular, yang terdiri dari tipografi dan ilustrasi. Penelitian ini untuk mengkaji faktor-faktor yang bersangkutan dengan graphic vernacular yang dapat dijadikan sebagai alat identitas dan sistem tanda. Hasil dari penelitian ini adalah bahwa graphic vernakular yang terdapat pada spanduk warung tenda dapat menjadi identitas sekaligus sistem tanda yang mudah untuk diidentifikasi masyarakat.
\end{abstract}

Kata kunci: graphic vernakular, warung tenda, identitas, sistem tanda, Kota Malang 
Yon Ade Lose Hermanto

IDENTIFIKASI ILUSTRASI-TIPOGRAFI GRAPHIC VERNACULAR SEBAGAI SISTEM TANDA \& IDENTITAS WARUNG TENDA DI KOTA MALANG

\section{Pendahuluan}

Kota Malang merupakan kota terbesar kedua di Provinsi Jawa Timur, setelah Ibu Kota Provinsi, Surabaya. Dengan luas $\pm 145,28 \mathrm{Km}^{2}$ Kota Malang memiliki jumlah penduduk sebesar 871.145 Jiwa (Permendagri No.66 Tahun 2011). Jumlah tersebut belum ditambah dengan jumlah penduduk dari kota lain yang tinggal sementara di Kota Malang, mengingat Malang merupakan Kota Pendidikan dengan banyak universitas.

Pertumbuhan penduduk yang sangat pesat ini mendorong sektor ekonomi terus berkembang, begitu juga pada sektor kuliner warung tenda yang tumbuh terutama pada daerah-daerah urban karena memang warung tenda menyajikan berbagai pilihan makanan dan minuman yang terjangkau untuk kalangan ekonomi menengah ke bawah. Dalam hal ini, Malang sebagai kota Pendidikan memiliki banyak calon konsumen, terutama dari jumlah mahasiswanya. Hal ini mendorong masyarakat Kota Malang untuk memanfaatkan kesempatan dengan membuka berbagai macam bisnis sektor kuliner, mulai makanan rumahan sampai dengan kuliner berbasis eksperimental dengan memakai nama-nama identitas yang menarik perhatian.

Bisnis kuliner warung tenda yang menjamur di Kota Malang memanfaatkan sistem identitas untuk pengenal dan pembeda antar usaha. Sistem identitas ini memanfaatkan elemen-elemen grafis/visual sebagai cara untuk menarik perhatian, mengenalkan brand, serta sebagai cara berkomunikasi dengan masyarakat sebagai calon konsumennya.

Dalam bisnis kuliner warung tenda, sistem identitas sangat diperlukan untuk promosi dan sebagai tanda pengenal yang khas. Sistem identitas ini membuat konsumen mudah mengenali varian makanan yang disediakan di warung tenda. Biasanya sistem identitas untuk warung tenda ditulis/digambar langsung pada tenda yang dipakai sebagai penutup luar tenda tersebut. Bahan dan teknik yang digunakan dalam membuat sistem identitas ini bermacammacam. Ada yang memakai teknik digital printing dengan medium cetak bahan frontlite, ada pula yang masih memakai teknik gambar/lukis manual dengan medium kain spanduk.

Teknik gambar/lukis manual untuk warung tenda memiliki kekhasan tersendiri. Hal ini dapat dilihat dari berbagai macam bentuk (style) tipografi dan ilustrasi yang dibuat secara manual untuk mendukung sistem identitas warung tenda. Selain itu, ada beberapa karakteristik yang selalu tampil pada karya tipografi-ilustrasi warung tenda. Karya-karya inilah yang biasa disebut sebagai karya vernakular.

Istilah vernakular bermula dari bidang linguistik berupa dialek-dialek regional dan sosial yang kemudian berkembang ke bidang arsitektur hingga ke desain komunikasi visual. Vernakular, berasal dari bahasa Latin yaitu vernacullus yang berarti lokal, pribumi atau bisa juga diartikan sebagai bahasa nasional yang non-standar dan muncul dari beragam budaya lokal yang membentuk dialek. (Abdiansyah, 2013:66)

Karya grafis vernakular merupakan salah satu bagian dari street graphics, dimana karya ini menonjolkan ciri khas lokal, baik itu dari segi bentuk tipografi, maupun gaya ilustrasi. Karya lokal semacam ini sangat penting untuk didokumentasikan karena didalamnya terkandung bermacam ciri khas dari berbagai daerah yang dapat menambah kekayaan graphics style lokal.

Penelitian mengenai graphic vernacular yang terdahulu dapat kita lihat pada penelitian Riama M. Sihombing dkk. mengenai gaya tulisan jalanan. Hal merupakan temuan yang membantu memahami perancangan tipografi vernacular. Gagasan rancangan tipografi dapat ditemukan dari mana saja dalam bentuk apa saja, seperti dari tulisan tangan seseorang, dari gambar grafiti di jalanan, ornamen pada barang sehari-hari, juga bentuk non abjad dapat bertindak sebagai tema atau inspirasi. Berdasarkan premis yang sama, jenis huruf dapat bekerja sebagai representasi dari eksistensi atau ekspresi. (Murtono, 2014:118). Teknologi yang semakin cepat berkembang pada sektor printing mengakibatkan tantangan berat bagi para seniman dan pengguna grafis vernakular. Sebenarnya teknik yang dipakai dalam grafis vernakular ini merupakan teknik yang tinggi dalam dunia desain grafis, karena mengandalkan kemampuan dan skill craftmanship yang sangat baik dan pengalaman yang panjang. Karya-karya vernakular kerap dipakai pada sistem identitas korporat untuk menunjukkan style dari usaha mereka. Hal ini menunjukkan bahwa gaya desain grafis vernakular memegang peranan penting dalam sistem identitas. Kemampuan ini harus dilestarikan, karena pada kenyataannya, 
penggunaan gaya dan teknik grafis vernakular mendapatkan tantangan kuat dari teknik cetak digital yang lebih cepat dan relatif terjangkau.

\section{Ilustrasi}

Berdasarkan definisinya ilustrasi adalah seni gambar yang dimanfaatkan untuk memberi penjelasan atas suatu maksud atau tujuan secara visual (Kusrianto, 2007:140). Ilustrasi atau Gambar merupakan salah satu wujud simbol atau bahasa visual yang di dalamnya terkandungstruktur rupa seperti garis, warna dan komposisi. "Sebuah gambar bila tepat memilihnya, bisa memiliki nilai yang sama dengan ribuan kata, juga secara individual mampu untuk memikat perhatian" (Kusmiati et al, 1999:36).

Ilustrasi merupakan suatu cara untuk memperjelas suatu penjelasan verbal. Ilustrasi juga dapat berdiri sendiri tanpa bantuan penjelasan verbal. Tetapi kedua unsur ini bila dipadukan akan menjadi kekuatan untuk menjelaskan suatu hal. Mencoba Mendefinisikan ilustrasi akan selalu memunculkan banyak sudut pandang yang berbeda. Hal tersebut juga tentang siapa yang lebih awal membuat, yang dimulai dengan lukisan di gua-gua. Yang pasti, ilustrasi memiliki arti atau makna yang tersirat dari elemen-elemen pembentuknya, dan biasanya merupakan suatu bentuk komunikasi visual. Untuk membentuk suatu komunikasi visual, atau untuk memecahkan suatu masalah yang berkaitan dengan komunikasi visual, pemahaman tentang penciptaan ilustrasi sangatlah penting.

Apa yang membuat seni ini sangat populer dan menarik adalah bahwa ilmu ilustrasi dipenuhi perintah untuk mengkomunikasikan suatu hal, menggabungkan imajinasi, kreativitas, keahlian dan keterampilan untuk menceritakan suatu cerita secara visual dan mencptakan dunia baru. Dalam konteks pendidikan seni dan desain, kemahiran dalam pengamatan yang objektif tentang keahlian menggambar merupakan dasar dari penciptaan bahasa visual. Yang paling baik adalah ilustrasi itu dapat memberi kekuatan, menyindir, memprovokasi, dapat menghiasi, mengisyaratkan sesuatu, bersifat humor, bersifat cerdas, mengandung kritik, menginspirasi, mempesona, indah, menguatkan hidup, dan memperkaya batin. (Wigan, 2008:14).
Dengan kata kata lain, suatu gambar ilustrasi yang baik selalu dapat menyampaikan pesan yang dimuatnya. Seorang ilustrator harus mengupayakan dengan kerja keras untuk menyampaikan pesan-pesan kedalam gambar dengan visual yang unik agar tidak lekas hilang dari ingatan mata yang melihatnya. Visual ilustrasi yang mudah dimengerti akan mempercepat penyampaian pesan dalam suatu komunikasi visual yang terjadi antara ilustrasi dengan pengamat.

a. Fungsi ilustrasi

Menurut Kusmiati et a/ (1999:44-47)

Penglihatan selaku penangkap bahasa visual, merupakan indera yang memberi informasi yang cepat dan lengkap. Dengan ilustrasi maka pesan menjadi lebih berkesan, karena pembaca lebih mudah mengingat gambar daripada katakata.

1) Untuk menggambarkan suatu produk atau suatu ilusi yang belum pernah ada.

2) Menggambarkan kejadian atau peristiwa yang agak mustahil.

3) Mencoba menggambarkan ide abstrak.

4) Memperjelas komentar, biasanya komentar editorial, dapat berbentuk kartun atau karikatur. 5) Memperjelas suatu artikel untuk bidang medis atau teknik.

6) Menggambarkan sesuatu secara rinci.

7) Membuat corak tertentu pada suatu tulisan yang menggambarkan masa atau zaman pada saat tulisan tersebut dibuat.

b. Teknik Ilustrasi

Terdapat beberapa teknik ilustrasi menurut Kusrianto (2007:140-162), Diantaranya: ilustrasi teknik Woodcut, ilustrasi cetak (Woodblock), Ilustrasi Fine Art, ilustrasi Computer Graphic.

\section{Tipografi Vernakular}

Secara bahasa, vernakular berasal dari kata vernaculus dengan kata verna artinya budak yang lahir di area rumah tuannya, yang kemudian diartikan juga sebagai bahasa daerah, logat asli, dialek seperti diutarakan dalam bahasa sehari-hari, atau yang berbeda dengan bahasa formal yang diajarkan di sekolah (Concept, 2011). Ilustrasi-Tipografi vernakular adalah gaya ilustrasi-tipografi yang craftmanship nya dikerjakan secara manual dengan memanfaatkan skill dan keterampilan tangan dari senimannya. Inilah seni "pinggiran", seni dari urban. 
Sangat menarik memang ketika kita memperhatikan desain dari "pinggiran" ini. Gambar orang mengangkat jempol untuk menunjukkan masakan yang enak, atau melihat deretan huruf dengan tipografi yang berbeda hasil kreativitas pembuatnya. Karya grafis vernakular tampil dalam berbagai bentuk, dari yang sangat sederhana hingga yang membutuhkan konsentrasi tinggi untuk memahaminya.

Menurut Sumbo (2011), desain vernakular memang mengesampingkan dogma-dogma dan pakem desain. Para penganut desain vernakular menganggap bahwa hal tersebut sebagai bentuk komunikasi visual yang bebas merdeka tanpa dibatasi oleh segala teori atau batasanbatasan. Mereka sangat natural ketika ingin memvisualisasi kehendak hatinya. Target komunikan yang dituju juga dapat dengan mudah memahami pesan yang ingin disampaikan.

Perancangan tipografi vernakular acap kali dijadikan sebagai wadah ekspresi bagi si pembuatnya dengan mengedepankan penyampaian informasi yang efisien dan efektif sehingga terkesan mengaburkan prinsip desainnya. Salah satu hal yang menarik dari tipografi vernakular yang termasuk di dalam 'desain grafis jalanan' ini adalah peran serta masyarakat awam dalam mengaplikasikan ilmu-ilmu desain dalam kehidupan sehari-hari yang cukup tinggi.

Mereka yang notabene belum pernah mengenyam pendidikan ilmu seni dan desain grafis tanpa sadar telah menerapkan beberapa dasar keilmuan tersebut di berbagai media, baik yang digunakan sebagai identitas promosi bagi usaha mereka maupun bentukbentuk ekspresi seni lainnya. Entah disengaja atau tidak, seakan-akan ada sistematika tertentu yang diterapkan dalam perancangan desain grafis jalanan, seperti penerapan fungsional tulisan dan gambar sebagai identitas, informasi bahkan sign system dan promosi. Pada perancangan desain grafis jalanan ini lebih sering ditemukan layout rata tengah (centered), penggunaan huruf kapital, penambahan outline dan efek-efek dalam usaha menjadikan tulisan terlihat stand out, kerning yang tidak merata, dan seringnya ada usaha untuk meniru teknologi dan tren huruf pada setiap masanya.

Inilah yang kemudian dijadikan acuan dalam menguraikan prinsip tipografi, khususnya tipografi vernakular pada kedua karya mahasiswa DKV ISI Yogyakarta angkatan 2013, yaitu Habiburahman dan Yusuf Nugroho. Keduanya menyampaikan prinsip tipografi vernakular berdasarkan observasi yang telah mereka lakukan sebelumnya. Habiburahman menyoroti tipografi vernakular yang terdapat di beberapa warung pecel lele. Ia membagi prinsip tipografi vernakular menjadi tiga, yaitu hirarki yang berkaitan dengan sequence (urutan) penyampaian informasi, konvensi yang berkaitan dengan pendekatan teknologi yang digunakan, dan dekoratif yang erat kaitannya dengan bentuk dan anatomi hurufnya.

Ia melihat prinsip hirarki dari sequence (urutan) informasi yang disampaikan dengan memberikan penekanan (emphasis) baik itu warna, ukuran, arah, dan posisi teks. Selanjutnya, ia menjadikan pendekatan teknologi yang digunakan dalam perancangan tipografi vernakular sebagai acuan dalam menulis prinsip tipografi yang kedua, yaitu prinsip konvensi. Sedangkan, pada prinsip ketiga yang ia tulis, penekanan pada bentuk dan anatomi yang dilihat menjadi alasanya memasukkan prinsip dekoratif sebagai salah satu dari ketiga prinsip yang ia tuangkan dalam karyanya.

\section{Warung Tenda Di Kota Malang}

Data sample untuk penelitian ilustrasitipografi vernakular ini adalah memakai dua warung tenda yang memiliki jaringan/cabang yang cukup luas di Kota Malang. Dua warung tenda ini adalah Warung Lalapan Cabang Purnama dan Warung Lalapan Cak Tomo. Warung-warung ini memiliki beberapa cabang di beberapa tempat di Kota Malang.

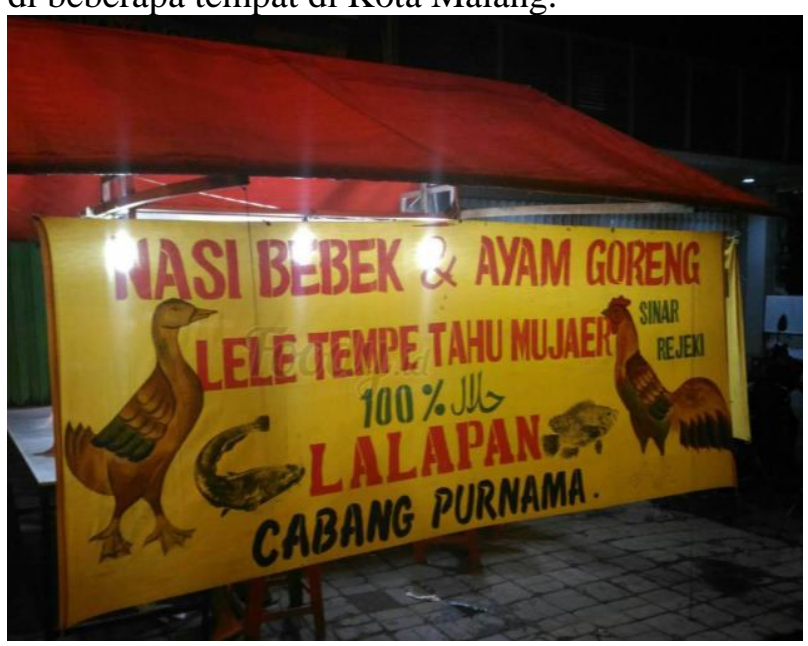


Gambar 1. Desain Ilustrasi dan Tipografi Warung Tenda Lalapan Cabang Purnama Jl. Galunggung Malang

Warung tenda Lalapan Cabang Purnama mudah kita jumpai di beberapa Titik di Kota Malang. Ada 30 cabang warung lalapan yang sekarang beroperasi di Kota Malang. Desain ilustrasi tendanya memiliki ciri khusus yang memudahkan pelanggan mengidentifikasinya. W. Header (menu) 17.00 WIB -23.00 viD. Ivicilu vally ditawarkan antara la Header (menu) goreng, lele, Mujair, yang semuanya ditam (semacam olahan $\mathrm{p}$ goreng). Menurut Cho warung tenda cabang Ilustrasi menu disediakan tidak senruarrya uा vuat musuasi tenda. Hanya maksimal empat menu yang digambar ada tenda. Warung lalapan Purnama lebih fokus pada pesan tulisan (tipografi) serta warna tenda sebagai sarana identitas dan komunikasi pada para pelanggannya.

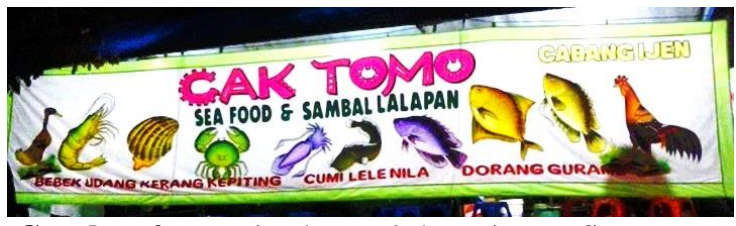

Gambar 2. Desain Ilustrasi dan Tipografi Warung Cak Tomo Sea Food \& Sambal Lalapan, Jl. Ijen, Malang (Seberang Gereja Ijen)

Berpusat di kawasan Oro oro dowo tepatnya di jalan Brigjen Slamet Riadi 173 C Malang, Cak Tomo menawarkan aneka menu lalapan seperti Ikan Goreng/Bakar, Kerang, Cumi, Udang hingga Kepiting yang dihidangkan dengan berbagai citarasa mulai dari asem manis, saos padang, saos tiram, mentega maupun rebus. Selain aneka menu utama, Cak Tomo Sea Food juga menghadirkan menu pelengkap lainnya yang pantang untuk dilewatkan seperti cah kangkung dan tempe penyet. Warung Cak Tomo awalnya buka kaki lima di Jalan Ijen di seberang Gereja Ijen. Namun sekarang Warung Cak Tomo membuka tempat tetap berpusat di Oro Oro Dowo Malang (Jalan Brigjen Slamet Riyadi), Cak Tomo juga membuka beberapa cabang lainnya di Kota Malang antara lain di daerah Sulfat dan Mayjen Panjaitan. Seperti warung lalapan sea food lainnya, Warung Cak Tomo baru akan buka setiap harinya mulai pukul $17.00-00.00 \mathrm{WIB}$.

\section{Sequence Pesan \& Tipografi}

Tipografi merupakan pemilihan, pemilahan dan pengaturan tata letak yang harmonis serta mengandung maksud tertentu dari huruf yang ditampilkan (divisualisasikan) dalam berbagai media. Tipografi pada desain periklan cetah di media massa adalah head line, sub head line,dan body copy (Pujiyanto, 2013:213). Ilustrasi dan tipografi vernakular dipakai menjadi artwork untuk media identifikasi dari warung tenda. Artworks yang digunakan oleh para pemilik warung tenda pingir jalan ini biasanya dibuat dengan teknik manual, ilustrasi tersebut menggambarkan menu masakan olahan yang tersedia seperti ayam goreng, bebek goreng, ikan goreng/bakar, udang goreng/krispi, kepiting goreng, dan lainnya. Ilustrasi yang digambarkan juga bisa berupa gambar hewan yang menjadi menu dari warung tenda tersebut.

Urutan informasi atau sequence yang ditampilkan pada Warung Lalapan Purnama lebih ditekankan pada pesan menu warung tersebut. Diawali dengan penekanan pada teks "Nasi Bebek dan Ayam Goreng". Ukuran huruf lebih besar dari ukuran huruf lainnya. Typeface ini memakai pewarnaan merah dengan background kuning. teks vernakular yang dimunculkan pada pesan di waung tenda ini berasal dari cara pembuatannya dengan menggunakan teknik gambar manual, dengan menggunakan teknik stencil agar konsistensi bentuk huruf baik. Huruf yang digunakan berjenis sans serif, kecuali pada tulisan "Lalapan", yang menggunakan jenis huruf Slab.

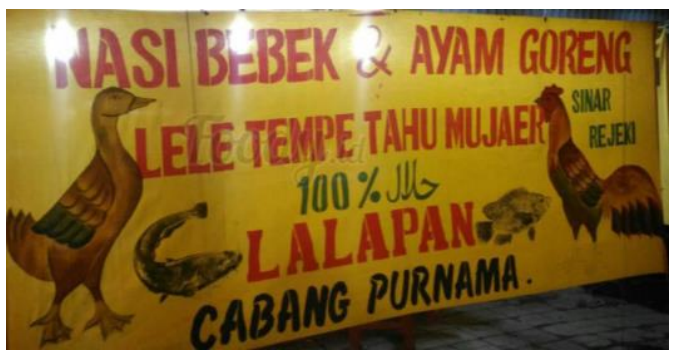


Gambar 3. Urutan informasi (sequence) dari desain Ilustrasi dan Tipografi Warung Lalapan Cabang Purnama

Sedangkan pada gambar 4 yaitu Warung Tenda Lalapan Cak Tomo, sequence informasi yang menjadi pusat perhatian adalah tulisan Cak Tomo, dengan ukuran huruf yang lebih besar dari huruf yang lain, serta menggunakan klasifikasi huruf sans serif ornamental. Typeface berwarna magenta, dengan menggunakan bayangan warna hitam sehingga menjadi sangat kontras dengan latar belakang kain yang berwarna putih. Ilustrasi yang digunakan juga lebih banyak, yaitu gambar bebek, udang, kerang, kepiting, cumi, lele, nila, dorang, gurami, dana yam, karena memang pilihan menu di warung ini lebih banyak. Di bawah ilustrai hewan-hewan tersebut, ditambah tulisan nama-nama hewan yang bersangkutan untuk memperkuat dan memperjelas kandungan pesan, berupa menumenu yang disediakan oleh Warung Lalapan Cak Tomo. Sequence pesan yang termuat dalam ilustrasi warung Lalapan Cak Tomo adalah sebagai berikut:

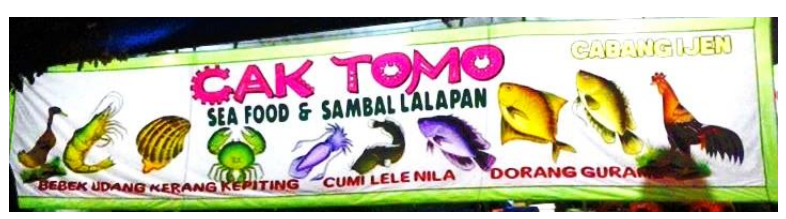

Gambar 4. Urutan informasi (sequence) dari desain Ilustrasi dan Tipografi Warung Lalapan Cak Tomo

\section{Hirarki Dan Kontras}

Hirarki huruf serta ilustrasi pada warung-warung tenda yang dibuat secara vernacular dapat diartikan sebagai arah atau alur baca atau alur penyajian informasi, dan juga sebagai pembeda antara header dan isi teks serta ilustrasi. Bentuk huruf, ukuran huruf, serta warna huruf dapat menjadi pembeda dan hirarki untuk pesan tekstual. Sedangkan style ilustrasi, serta warna dan ukuran ilustrasi dapat menampilkan identitas $\sqrt{\text { Header (identitas) }}$ lainnya.

Menurut Gavin Keterangan warung hirarki dalam tipograf Ilustrasimenu

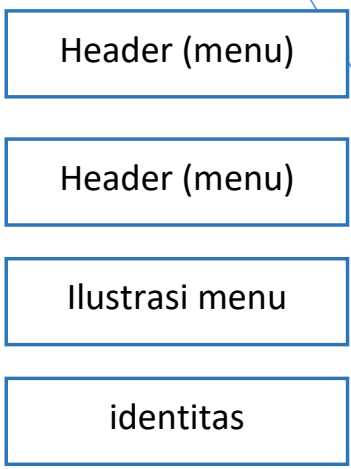

pemberi kesan layout yang bersih, tidak ambigu dan mudah untuk diarahkan. Hirarki dapat berbentuk ukuran berat font yang berbeda, ukuran point serta gaya dan klasifikasi. Sebuah hirarki yang sederhana dapat diciptakan dengan memberikan warna yang berbeda pada huruf yang sama (Ambrose \& Harris, 2009: 82).

Kontras adalah prinsip desain untuk memperjelas pesan dan posisi dari teks dan ilustrasi. Kontras merupakan unsur yang penting untuk mendukung keterbacaan dan kejelasan informasi yang ditampilkan. Rangkaian huruf yang ditampilkan harus mudah untuk dibaca dan dikenali bentuknya. Menurut Cronin (2011), Kontras merupakan unsur terpenting dalam memberikan kesan sebuah kata, kalimat atau paragraf mudah tidaknya untuk dibaca. Kontras yang baik menjadikan sebuah kata, kalimat atau sebuah paragraf mudah untuk dibaca dan memudahkan mata dalam mengenali huruf-huruf tersebut (Cronin, 2011: 27).

Pada gambar 5, kontras huruf yang berwarna merah dan hitam dengan background berwarna kuning membuat pesan atau informasi yang disampaikan di tenda tersebut menjadi mudah dikenali. Ukuran huruf yang besar membuat pesan mudah dibaca meskipun dari jarang yang jauh. Ilustrasi dengan ukuran besar juga dapat memperkuat isi pesan tekstual. Dengan begitu, warung Lalapan Cabang Purnama ini sangat mudah dikenali. Kontras yang sangat jelas dapat dilhat dari ujicoba memakai warna black and white monochrome. 


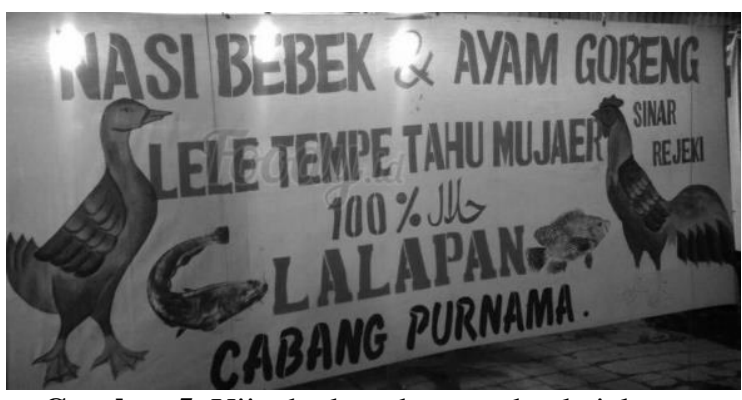

Gambar 5. Ujicoba keterbacaan dan kejelasan dengan memakai monochrome mode dari desain Ilustrasi dan Tipografi Warung Lalapan Cabang Purnama

Selanjutnya, pada tenda warung Lalapan Cak Tomo, karena ukuran form tenda yang memanjang, maka dapat dimanfaatkan untuk menyampaikan pesan lebih banyak. Dapat dilihat, Cak Tomo menampilkan banyak sekali elemen grafis tanpa takut kejelsan dan keterbacaannya turun, karena memang ukuran media yang dipakai lebih besar. Dengan menggunakan backgrpund putih, ilustrasi dan tipografi yang dipakai memakai warna-warna yang kontras sehingga dengan mudah diidentifikasi dan dilihat dari jarak jauh. Ukuran media yang besar serta pencahayaan yang cukup juga mendukung kejelasan spanduk Cak Tomo. Bila diuji dengan warna monochrome pun, spanduk warung Cak Tomo masih cukup jelas kontrasnya. Hal ini dapat dilihat dari percobaan dengan mengubah desain menjadi black and white monochrome mode.

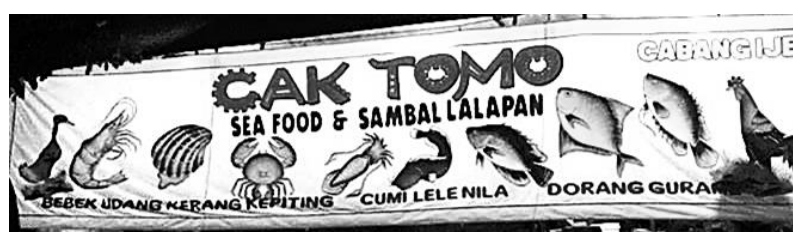

Gambar 6. Ujicoba keterbacaan dan kejelasan dengan memakai monochrome mode dari desain Ilustrasi dan Tipografi Warung Lalapan Cak Tomo

Pada Gambar 6.6, yang menjadi header adalah tulisan Cak Tomo dengan klasifikasi tulisan sans serif dengan menggunakan efek shadow, kemudian identitas cabang tempat dengan klasifikasi tulisan sans serit tanpa ornamen dengan outline dan shadow berwarna hitam, kemudian body text menggunakan sans serif. Latar belakang kain yang digunakan berwarna putih kemudian diberi border kain berwarna hijau, dengan ilustrasi banyak gambar hewan menjadi daya tarik masyarakat untuk memperhatikan desain tersebut sekaligus menunjukkan identitas dari warung lalapan Cak Tomo. Menu yang digambarkan dengan ilustrasi tersebut memberikan informasi yang lengkap tentang jenis usaha dari warung tenda ini.

\section{Ilustrasi Pada Tenda Warung}

Jika kita perhatikan ilustrasi tenda pada warung pinggir jalan di kota Malang dengan sample warung lalapan Purnama dan Warung Lalapan Cak Tomo yang sama-sama memiliki cabang di beberapa sudut kota, maka akan tampak beberapa ciri yang spesifik yang menjadi ciri khas dari tiap warung tersebut.

Tabel Ilustrasi Hewan pada tenda warung lalapan

\begin{tabular}{|l|l|c|c|}
\hline No & $\begin{array}{l}\text { Ilustrasi } \\
\text { Hewan }\end{array}$ & $\begin{array}{l}\text { Lalapan } \\
\text { Purnama }\end{array}$ & $\begin{array}{l}\text { Lalapan } \\
\text { Cak Tomo }\end{array}$ \\
\hline 1. & Ayam & $\sqrt{ }$ & $\sqrt{ }$ \\
\hline 2. & Bebek & $\sqrt{ }$ & $\sqrt{ }$ \\
\hline 3. & Lele & $\sqrt{ }$ & $\sqrt{ }$ \\
\hline 4. & Mujair & $\sqrt{ }$ & $\mathrm{X}$ \\
\hline 5. & Udang & $\mathrm{X}$ & $\sqrt{ }$ \\
\hline 6. & Cumi & $\mathrm{X}$ & $\sqrt{ }$ \\
\hline 7. & Kepiting & $\mathrm{X}$ & $\mathrm{V}$ \\
\hline 8. & Nila & $\mathrm{X}$ & $\sqrt{ }$ \\
\hline 9. & Dorang & $\mathrm{X}$ & $\sqrt{ }$ \\
\hline 10. & Gurami & $\mathrm{X}$ & $\sqrt{ }$ \\
\hline 11. & Kerang & $\mathrm{X}$ & $\sqrt{ }$ \\
\hline
\end{tabular}

Dari identifikasi ilustrasi hewan di atas, Warung Lalapan Purnama lebih sedikit memakai ilustrasi hewan sebagai menu makanannya karena form yang dipakai kecil. Sedangkan Warung Cak Tomo memakai banyak pesan visual berupa ilustrasi hewan karena memang form atau media yang dipakai lebih besar daripada tenda Lalapan Purnama. Ukuran media menentukan jumlah ilustrasi yang dipakai pada spanduk tenda warung.

\section{Background}

Background ilustrasi dan tipografi pada suatu desain menentukan kejelasan dan keterbacaan desain tersebut. Background dapat memperjelas pesan yang disampaikan, atau dapat pula membuat informasi menjadi susah ditangkap, tergantung bagaimana pengguna memakainya. Kesesuaian penggunaan background akan sangat membantu kelangsungan penyampaian pesan kepada masyarakat. 
Yon Ade Lose Hermanto

IDENTIFIKASI ILUSTRASI-TIPOGRAFI GRAPHIC VERNACULAR SEBAGAI SISTEM TANDA \& IDENTITAS WARUNG TENDA DI KOTA MALANG

Pada tenda Warung lalapan Purnama, background yang dipakai konsisten memakai warna oranye. Hal ini merupakan kekuatan tersendiri bagi warung tenda ini, karena tenda berwarna oranye sangat mudah untuk ditangkap mata. Terlebih lagi semua cabang warung di berbagai tempat juga memakai warna background oranye. Dari segi penyampaian pesan dan indetitas, oranye menjadi warna brand bagi warung Lalapan Purnama. Tidak ada warung lalapan lain yang memakai background berwarna oranye. Meskipun form atau ukuran spanduk tenda kecil, hanya sekitar $3 \times 1,5$ meter, dengan konsistensi ini, warung lalapan Purnama mudah sekali untuk diidentifikasi.

Sedangkan pada warung Cak Tomo, background yang dipakai adalah warna putih. Warna ini merupakan warna umum yang digunakan untuk membuat spanduk. Tetapi yang menjadi pembeda dari warung yang lain adalah ukuran spanduk yang besar, sekitar $7 \mathrm{x}$ 1,5 meter, membuat tenda ini terlihat dari jauh, dengan pesan yang sangst jelas pula terlihat dari jarak jauh. Ditambah lagi warna yang dipakai pada ilustrasi dan tipografi sangat kontras dengan warna background, membuat pesan sampai dengan jelas. Selain itu, warung lalapan Cak Tomo menggunakan penerangan dengan intensitas yang tinggi. Cahaya ini dapat membantu pesan pada tenda sampai pada mata masyarakat, meskipun jaraknya jauh dan dengan waktu yang singkat.

\section{A. Prinsip Desain}

Warung Tenda Lalapan cabang Purnama

\section{Readability}

Pada warung lalapan Purnama, readability pesan jelas karena memakai ukuran huruf yang besar, sehingga memungkinkan masyarakat melihat dan membacanya dari jarak jauh. Pesan yang sampaikan juga cukup singkat menjadikannya cepat dibaca dan dicerna oleh masyarakat. Kelemahan dari warung ini adalah pencahayaan yang kurang terang sehingga dapat mempengaruhi keterbacaan beberapa orang.

\section{Visibility}

Penggunaan warna tenda oranye sebagai background membuat warung tenda lalapan Purnama sangat mudah untuk diidentifikasi. Ukuran tulisan dan ilustrasi yang mendominasi media spanduk tenda memiliki visibility yang tinggi. Secara keseluruhan, visibility warung tenda lalapan
Purnama sangat mudah diidentifikasi karena konsistensi layout, serta pemakaian background tenda yang sama tiap cabangnya.

3. Legibility

Kejelasan bentuk tulisan dari warung tenda lalapan Purnama sangat tinggi. Hal ini dikarenakan pemilihan tipe huruf yang baik. Font yang dipakai berjenis sans serif dan memakai bentuk huruf kapital. Dengan begitu, secara individu tiap huruf memiliki bentuk yang berbeda dengan huruf lainnya. Tidak adanya ornamen desain serta pengukuran jarak antar huruf yang sesuai membuat legibility dari warung tenda ini sangat baik. Kotras warna antara background dan warna tulisan juga menguatkan kejelasan dari penyampaian pesan yang ada di spanduk warung tenda lalapan Purnama.

4. Clarity

Hirarki dari huruf dan ilustrasi pada warung tenda lalapan Purnama tidak terlalu tinggi karena form yang kecil, sehingga penataan tiap teks menjadi berhimpitan. Secara keseluruhan clarity dari graphic vernacular warung tenda lalapan Purnama tidak terlalu rendah karena pemilihan huruf yang seusi dan mudah dibaca, serta ukuran huruf yang besar dengan tipe huruf kapital.

\section{Warung Tenda Lalapan Cak Tomo}

\section{Readability}

Warung lalapan Cak Tomo memiliki readability dari pesan jelas karena memakai ukuran huruf yang besar, sehingga memungkinkan masyarakat melihat dan membacanya dari jarak jauh. Form yang luas untuk menyampaikan pesan membuat pemakaian huruf dan ilsutrasi menjadi lebih leluasa. Pencahayaan yang cukup kuat juga mendukung readability sehingga masyarakat dengan mudah menangkap pesan yang terkandung dalam spanduk tenda warung Cak Tomo.

\section{Visibility}

Warna tenda putih bersih dengan pencahayaan yang kuat membuat warung tenda Cak Tomo memiliki visibility yang tinggi. Ukuran form atau medium penyampaian pesan yang besar secara langsung dapat dilihat masyarakat. Bagi warung lalapan Cak Tomo, hal ini adalah salah satu kekuatan visual untuk menyampaikan pesan dan sebagai identitas 
meraka. Pemilihan warna huruf dan ilustrasi menjadi kontras dengan background.

\section{Legibility}

Bentuk huruf berornamen yang dipakai untuk headline dari warung tenda lalapan Cak Tomo masih memiliki legibility yang cukup baik. Hal ini dikarenakan ornamen yang menempel pada huruf tidak mengganggu bentuk huruf secara keseluruhan. Memang secara harmoni, bentuk font yang dipakai, yaitu Jokerman, kurang sesuai dengan interpretasi semantik dari warung lalapan. Untuk penyampaian pesan berupa menu makanan, warung Cak Tomo memakai dua bentuk penyampaian sekaligus, yaitu memakai ilustrasi dan dibwah ilustrasi tersebut diperkuat dengan tulisan yang menjelaskan ilustrasi.

\section{Clarity}

Karena menggunakan media spanduk dengan ukuran yang besar (7 x 1,5 meter), maka warung lalapan Cak Tomo lebih leluasa untuk meletakkan elemen grafis sebagai identitas warung dan informasi. Hirarki yang cukup baik karena space form yang luas membuat clarity dari desain graphic vernacular warung tenda lalapan Cak Tomo menjadi tinggi. Dengan clarity yang baik, maka penyampaian pesan ke masyarakat menjadi lebih cepat dan jelas.

\section{Kesimpulan}

Dari pembahasan tentang identifikasi Ilustrasi dan tipografi Vernakular Warung Tenda Di Kota Malang, maka dapat diambil beberapa kesimpulan, diantaranya:

1. Gaya desain vernacular merupakan gaya dasain dengan teknik manual yang tetap bertahan di era digital. Teknik ini secara tidak langsung telah memberikan kekayaan visual pada suatu daerah.

2. Vernakular sebagai salah satu ciri khas suatu daerah, dapat pula menjadi sistem identitas bagi daerah tersebut. Dengan konsisten menampilkan suatu karya graphic vernacular, maka dengan sendirinya dapat menanamkan citra pada masyarakat tentang eksistensi pemakai desain.

3. Masyarakat, khususnya kalangan menengah, masih gemar memanfaatkan finishing dari teknik vernacular karena dianggap lebih murah dan muda dikenal, daripada menggunakan teknik digital.

4. Tipografi vernakular sampai sekarang belum tergantikan keberadaannya, walaupun sudah memasuki era ndigital. Hampir di seluruh pelosok negeri masih mempertahankan desain spanduk dengan memakai ilustrasi dan tipografi vernakular.

5. Standarisasi desain ilustrasi dan pesan pada tenda yang dilakukan pemilik warung tenda pada cabang-cabang usaha warung mereka membuat masyarakat dengan mudah mengidentifikasi keberadaan dan eksistensi warung tersebut. Warung Lalapan Cabang Purnama selalu memakai background oranye dengan sedikit ilustrasi dan ukuran huruf yang besar menjadi kekuatan tersendiri dalam menampilkan indentitas dan memberikan informasi menu. Sedangkan Warung Cak Tomo memiliki kekuatan berupa ukuran media/form yang lebih besar, sehingga dapat dimanfaatkan untuk memberikan informasi berupa ilustrasi menu yang lebih banyak. Warna identitas warung yang kontra dengan background putih membuat masyarakat juga dengan mudah mengenali warung ini.

Secara keseluruhan, identitas dari dua warung tenda lalapan ini mudah untuk diidentifikasi meskipun keduanya memiliki kekuatan grafis yang berbeda. Warung tenda lalapan Purnama lebih menekankan pada pesan yang singkat dengan ukuran huruf yang mendominasi form, serta sedikit memakai ilustrasi hewan dan pemakaian background berwarna oranye sebagai identitas warna. Sedangkan warung lalapan Cak Tomo memiliki keunggulan pada ukuran form yang lebih besar, pencahayaan yang lebih terang, memakai banyak ilustrasi hewan untuk menegaskan identitas dan eksistensi dari warung tersebut. Dua kekuatan yang berbeda ini memang dapat diterapkan pada warung tenda lainnya, tergantung dari lokasi berjualan, luas lahan untuk warung, serta sumber daya energi untuk pencahayaannya.

\section{Daftar Pustaka}

Abdiansyah, Nur. 2013. Tipografi Vernakular Sandeq Mandar dan Proses Penciptaannya. 
Jurnal Media, Seni, Desain, dan Pengajarannya, Tahun ke-4 Edisi ke 2, November 2013. Malang: Universitas Negeri Malang

Ambrose, Gavin. \& Harris, Paul. 2009. The Fundamentals of Graphic Design. Lausanne, Switzerland: AVA Publishing SA.

Concept Majalah Desain Grafis. 2011. Jakarta: Concept Media

Cronin, Matt. 2011. 10 Principles For Readable. In: Typography: Getting the Hang of Web Typography. Freiburg: Smashing Media $\mathrm{GmbH}$

Darmaprawira, Sulasmi. 2002. Warna Teori dan Kreativitas Penggunanya. Bandung: PENERBIT ITB.

Kartoredjo R, H.S. 2014. Kamus Baru Kontemporer. Bandung: PT. REMAJA ROSDAKARYA.

Kumar, Vijay. 2013. 101 Metode Desain. Jakarta: PT. Elex Media Komputindo

Kusrianto, Adi. 2007. Pengantar Desain Komunikasi Visual. Yogyakarta : CV. Andi Offset.

Kusmiati R, Artini, dkk. 1999. Teori Dasar Desain Komunikasi Visual. Jakarta: Djambatan.

Murtono, Taufik. 2014. Penguatan Citra Merek Batik dengan Tipografi Vernacular. ACINTYA: Jurnal Penelitian Seni dan Budaya, Vol. 6 Nomor 2, Desember 2014. Solo: ISI Surakarta

Pujiyanto. 2013. Estetika Ideologi Media Above The Line Produk Suplemen Merek "Madurasa" PT. Air Mancur. Jurnal Bahasa dan Seni, Volume 41, nomor 2, Tahun 2013. Malang: Universitas Negeri Malang.

Rustan, Surianto. 2014. Layout Dasar dan Penerapanya. Jakarta: PT. Gramedia.

Sanyoto, Sadjiman Ebdi. 2006, Metode Perancangan Komunikasi Visual Periklanan.Yogyakarta: Dimensi Press.

Sarwono, J. \& Lubis, H. 2007. Metode Riset untuk Desain Komunikasi Visual. Yogyakarta: Penerbit ANDI.

Sihombing, Danton. 2015. Tipografi Dalam Desain Grafis (Edisi diperbaharui). Jakarta: PT. Gramedia

Tim Penyusun Pedoman Penulisan Karya Ilmiah, 2010. Pedoman Penulisan Karya Ilmiah, Malang, Penerbit Universitas Negeri Malang.
Tinarbuko, Sumbo. 2015. DEKAVE: Desain Komunikasi Visual, Penanda Zaman Masyarakat Global. Yogyakarta: CAPS (Center of Academic Publishing Service) 